\title{
In vitro antibacterial mechanism of action of crude Garlic (Allium sativum) clove extract on selected probiotic Bifidobacterium species as revealed by SEM, TEM and SDS-PAGE analysis
}

\section{J. Booyens, M.C. Labuschagne and M.S. Thantsha}

Department of Microbiology and Plant Pathology, University of Pretoria, Pretoria, South Africa

Correspondence: Mapitsi S. Thantsha, Faculty of Natural and Agricultural Sciences, Department of Microbiology and Plant Pathology, New Agricultural Sciences Building Room 9-10, Lunnon road, University of Pretoria, Pretoria, 0002, South Africa. Tel: +27 (0) 12420 4562, Fax: +27 (0) 12420 3266, email: mapitsi.thantsha@up.ac.za

\begin{abstract}
There has been much research on the effects of garlic (Allium sativum) on numerous pathogens, but very few, if any, studies on its effect on beneficial, probiotic bifidobacteria. We have recently shown that garlic exhibits antibacterial activity against bifidobacteria. The mechanism by which garlic kills bifidobacteria is yet to be elucidated. This study sought to determine the mechanism of action of garlic clove extract on selected Bifidobacterium species using scanning and transmission electron microscopy and SDS-PAGE analysis. SEM micrographs revealed unusual morphological changes such as cell elongation, cocci-shaped cells with crosswalls and distorted cells with bulbous ends. With TEM observed changes included among others, condensation of cytoplasmic material, disintegration of membranes and loss of structural integrity. SDS-PAGE analysis did not reveal any differences in whole cell protein profiles of untreated and garlic clove extract treated cells. The current study is the first to reveal the mechanism of action of garlic clove extract on probiotic Bifidobacterium species. The results indicate that garlic affect these beneficial bacteria in a manner similar to that exhibited in pathogens. These results therefore further highlight that caution should be taken especially when using raw garlic and probiotic bifidobacteria simultaneously as viability of these bacteria could be reduced by allicin released upon crushing of garlic cloves, thereby limiting the health benefits that the consumer anticipate to gain from probiotics.
\end{abstract}


Keywords: Garlic; Allium sativum; Bifidobacterium; scanning electron microscopy; transmission electron microscopy; probiotic

\section{Introduction}

Bifidobacteria are Gram-positive, anaerobic, non-sporeforming bacteria that form a significant part of the intestinal microflora in the gastrointestinal tracts of healthy humans. Occurrence of these bacteria within the GIT is an indication of good intestinal health $[14,22]$. Bifidobacteria are used in conjunction with lactobacilli in probiotic products due to their numerous health benefits which include prevention and treatment of allergies, gastrointestinal problems and immunodeficiencies [13, 22]. Bifidobacteria are also believed to reduce blood cholesterol, deconjugate bile acids as well as reduce traveler's diarrhea and antibiotic-associated diarrhea [14]. In order to confer the purported health benefits, these bacteria need to be available in sufficient amounts in probiotic-containing foods and products. It is worth noting that at the same time that probiotics are prescribed to consumers for health benefits, there are herbs such as garlic, which are also recommended for the same reasons.

Garlic (Allium sativum) has been used worldwide for many centuries as a spice and herbal medicine and is believed to treat and prevent various diseases [6]. It is a strong antibacterial agent and inhibits both Grampositive and Gram-negative bacterial growth, which includes Bacillus, Brusella, Klebsiella, Proteus, Pseudomonas, Shigella, Staphylococcus, Salmonella as well as Helicobacter pylori [9, 12]. The main component of garlic responsible for its antibacterial activity is allicin [19]. The enzyme allinase converts alliin into this volatile compound, once garlic is damaged by crushing or cutting $[12,26]$. Most antimicrobial agents are able to modify bacterial cell membranes and this leads to cell leakage and autolysis thereby preventing growth and causing cell death [19].

Garlic has been found to have a morphological effect on various bacterial cells, resulting in changes to the outer surfaces, internal properties as well as behavior of the cells $[6,15,18,23]$. Although there has been much research on the effect that garlic has on pathogenic bacteria, there are a very few studies on its effect on beneficial, probiotic bifidobacterial cells. We have recently shown that garlic does exhibit antibacterial effects 
against probiotic bifidobacteria [7]. The aim of the current study was to determine the mechanism of action of garlic on selected Bifidobacterium species using SEM, TEM and SDS-PAGE.

\section{Materials and Methods}

Bacterial cultures

Bifidobacterium lactis Bb12 (CHR- Hansen, Denmark), B. bifidum LMG 11041 and B. longum LMG 13197 (LMG Culture collection, Belgium) were used as test cultures.

\section{Preparation of inoculums}

Bifidobacterium cultures were grown in MRS-cys-HCL broth and incubated at $37^{\circ} \mathrm{C}$ for $48 \mathrm{~h}$ in anaerobic jars with Anaerocult A gaspacks and Anaerocult C test strips (Merck KGaA, Germany) for confirmation of anaerobic conditions. Bacterial cell suspensions were adjusted to a 0.5 McFarland standard (approximately $1 \mathrm{x}$ $\left.10^{8} \mathrm{cfu} \mathrm{ml}^{-1}\right)$.

\section{Preparation of garlic clove extract}

Fresh garlic cloves were purchased from a local supermarket in Pretoria and used within two weeks. The garlic clove extract was prepared as described by Bakri and Douglas [5], with slight modifications. Fresh cloves were separated and peeled and then $10 \mathrm{~g}$ was weighed and crushed using a mortar and pestle. This was suspended in $5 \mathrm{ml}$ sterile distilled water. The suspension was then centrifuged at $1677 \mathrm{~g}$ for $5 \mathrm{~min}$ and then filtered through a $0.22 \mu \mathrm{m}$ Ministart syringe filter (Sigma-Aldrich, USA). The weight of the insoluble material of the garlic clove was subtracted from the weight of the original material to get the final concentration of garlic in solution, which was determined to be $60.7 \%(\mathrm{w} / \mathrm{v})$. The concentration of allicin, the major active compound in the extract, was determined spectrophotometrically by reaction with 4-mercaptopyridine as described previously [7]. The sterile extract was used within 30 min of its preparation.

\section{Treatment of bifidobacteria with garlic clove extract}

Garlic clove extract was added to a total volume of $1 \mathrm{ml}$ of each Bifidobacterium broth culture, in triplicate. The final allicin concentration in each culture was equivalent to the minimum bactericidal concentration of 198.7, 99.4 and $39.8 \mu \mathrm{g} \mathrm{ml}^{-1}$ for B. lactis Bb12, B. bifidum LMG 11041 and B. longum LMG 13197, 
respectively, as previously determined [7]. Cultures were then incubated at $37^{\circ} \mathrm{C}$ for $6 \mathrm{~h}$ followed by centrifugation for $10 \mathrm{~min}$ at $12044,9 \mathrm{~g}$. Cells were resuspended in $1 \mathrm{ml} 1 / 4$ strength Ringer's solution.

\section{Scanning electron microscopy (SEM)}

The samples of Bifidobacterium spp. were observed under the scanning electron microscope before and after $6 \mathrm{~h}$ of garlic treatment. A modification of the method by Lai-King et al. [17] was used. Cells suspended in 1/4 Ringer's solution were harvested by filtering through a $0.2 \mu \mathrm{m}$ filter membrane. The cells were fixed to the membrane using $2.5 \%$ gluteraldehyde in $0.075 \mathrm{~mol}^{-1}$ phosphate buffer $(\mathrm{pH} 7.4)$ for $1 \mathrm{~h}$. They were then washed three times with $0.15 \mathrm{~mol}^{-1}$ phosphate buffer, and dehydrated in a graded alcohol series $(25,50,75,90$ and $100 \%$ ethanol). This was followed by critical-point drying for $24 \mathrm{~h}$ and the filters were mounted onto SEM specimen stubs and coated with gold. The samples were observed under a JEOL 780 and JEOL JSM-5800LV SEM (JEOL, Tokyo, Japan).

\section{Transmission electron microscopy (TEM)}

Garlic clove extract treated and untreated bacterial cultures $(1 \mathrm{ml}$ each) were centrifuged at $1677 \mathrm{~g}$ for $2 \mathrm{~min}$. The pellet was then fixed using $2.5 \%$ gluteraldehyde in $0.075 \mathrm{~mol}^{-1}$ phosphate buffer (pH 7.4). It was then rinsed three times in $0.15 \mathrm{~mol}^{-1}$ phosphate buffer and fixed in $0.5 \%$ osmium tetroxide. The sample was rinsed with distilled $\mathrm{H}_{2} \mathrm{O}$ and dehydrated in a graded series of ethanol (50, 70, 90 and 100\%) before being infiltrated with Quetol epoxy resin and allowed to polymerize for $39 \mathrm{~h}$ at $60{ }^{\circ} \mathrm{C}$. Ultrathin sections were cut and stained with aqueous uranyl acetate. The sections were then counterstained with lead acetate and rinsed in distilled $\mathrm{H}_{2} \mathrm{O}$. Monitor sections of $0.5 \mu \mathrm{m}$ were cut and stained in Toluidine blue. The samples were then viewed using a JEOL JEM-2100F microscope (JEOL, Tokyo, Japan).

\section{SDS-PAGE analysis}

Garlic clove extract treated and untreated samples $(1 \mathrm{ml}$ each) were transferred to Eppendorf tubes and cells were harvested by centrifugation at $1677 \mathrm{~g}$ for $2 \mathrm{~min}$. The pellet was subsequently washed three times with phosphate-buffered saline. The sample was then sonicated for $15 \mathrm{~s}$ at $30 \mathrm{~W}$ while on ice. Then $40 \mu \mathrm{l}$ of sample buffer was added and the sample was heated at $100^{\circ} \mathrm{C}$ for $10 \mathrm{~min}$ and cooled on ice. $20 \mu \mathrm{l}$ of the lysed cell product was run per lane on a $10 \%$ SDS gel at $100 \mathrm{~V}$ for $170 \mathrm{~min}$. The gels were stained overnight using a colloidal Coomassie blue stain ((BioRad, USA) and destained in distilled $\mathrm{H}_{2} \mathrm{O}$ for $1 \mathrm{~h}$. 


\section{Results}

Scanning electron microscopy micrographs revealed changes to the outer surface of Bifidobacterium cells exposed to garlic clove extract for $6 \mathrm{~h}$ (Fig. 1). The surfaces of all untreated cells were smooth and intact (Fig. 1a, d and g). Bifidobacterium bifidum LMG 11041 and B. longum LMG 13197 cells not treated with garlic clove extract had a uniform rod-shaped appearance (Fig. 1a and d) while B. lactis Bb12 cells were pleomorphic (Fig. 1g). After exposure of bifidobacteria to garlic clove extract there was an increase in highly distorted cells. Swollen cells, those with dumb-bell shaped appearance as well as those with bulbous ends were observed (Fig. 1b, c, h and i). Bifidobacterium bifidum LMG 11041 cells became coccoid shaped with cross-walls (Fig. 1b and c) and there was an increase in coccoid than rod shaped cells for B. lactis Bb12 cells (Fig. h and i). Pore formation and cell lysis was also apparent after garlic clove extract treatment (Fig. 1e, f and i). Disintegration of some cells and presence of debris in the vicinity of treated cells was also evident (Fig. 1e and h). Bifidobacterium treated cells appeared longer than untreated cells.

Transmission electron microscopy micrographs revealed intact cells with uniform cytoplasmic appearance and well defined walls and membranes for untreated bifidobacteria (Fig. 2a, d and g). However various morphological and intracellular changes were evident upon treatment of cells with garlic clove extract. Treatment of bifidobacteria with garlic clove extract resulted in aggregation or condensation of cytoplasmic contents, loss of structural integrity of the membranes and cell wall lysis with presence of debris evident in the lysed cells' surrounding environment (Fig. 2b, c, e, f, h and i).

SDS-PAGE analysis was also performed to determine whether there were any differences in protein profiles between untreated Bifidobacterium cells and those that were exposed to the garlic clove extract. There were no major differences in protein profiles of untreated and garlic extract treated bifidobacteria, except that a single band positioned between 130 and $250 \mathrm{kDa}$ was fainter in B. longum LMG 13197 treated than in untreated cells (data not shown).

\section{Discussion}

The differences in appearances of treated and untreated bifidobacteria cells suggested that garlic clove extract affected the structure of these bacteria. The morphological characteristics of all untreated cells as observed in the current study were similar to those published by researchers elsewhere. Lv et al. [21] reported smooth rod 

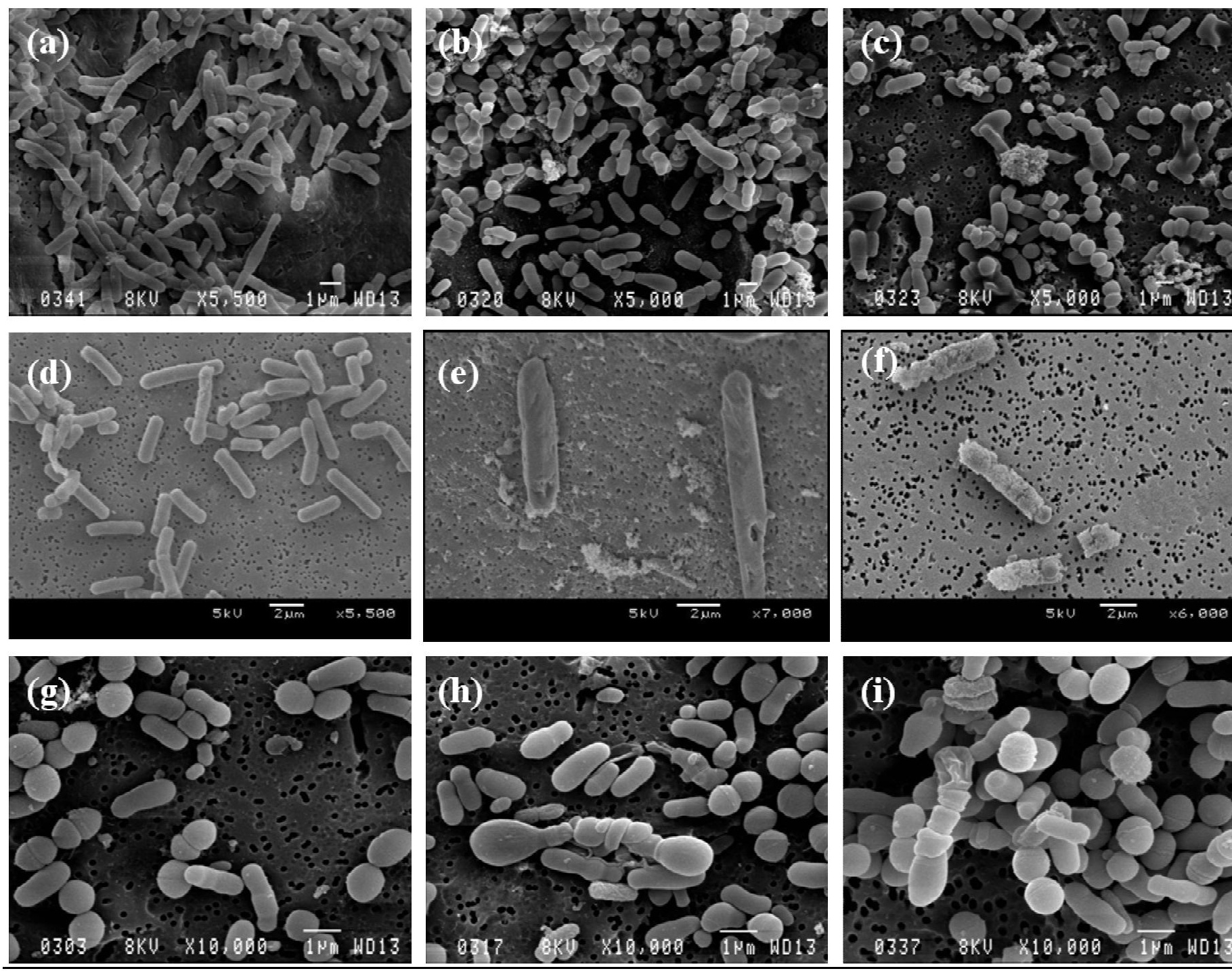

Fig. 1 Scanning electron micrographs of Bifidobacterium bifidum LMG 11041, untreated (a); treated (b, c); B.longum LMG 13197, untreated (d) and treated (e, f) and B. lactis Bb12, untreated (g) and treated $(h, i)$ cells. 

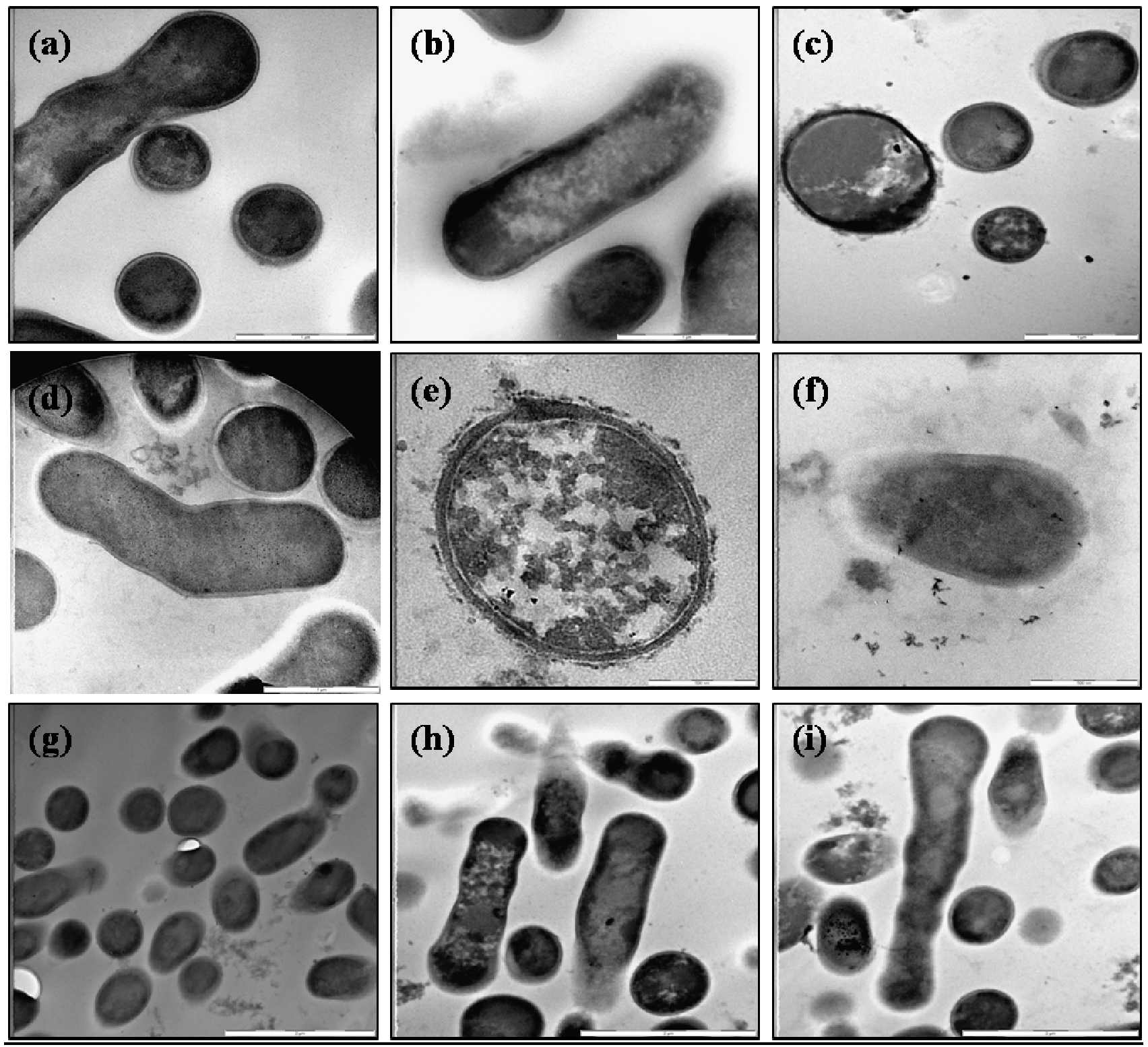

Fig. 2 Transmission electron micrographs of Bifidobacterium bifidum LMG 11041, untreated (a); treated (b, c); B. longum LMG 13197, untreated (d) and treated (e, f) and B. lactis Bb12, untreated $(\mathrm{g})$ and treated $(\mathrm{h}, \mathrm{i})$ cells. 
shaped cells for untreated bifidobacteria whereas a pleomorphic culture of untreated bifidobacterium cells was reported by [22, 24]. These researchers [22, 24] observed coccoid as well as branched, filamentous and swollen cells with cross-walls. Novik et al. [22] reported that during their death phase or periods of stress, bifidobacteria form coccoid and club-shaped cells. The observed cocooid shaped cells could also be attributed to cells entering death phase due to presence of allicin and other antimicrobial compounds present in the garlic clove extract. Cell wall lysis was also reported for Listeria monocytogenes treated with garlic shoot juice [15]. Cell wall degradation was proposed to be due to weakening of the peptidoglycan layer due to garlic extract exposure [15]. Changes caused by treatment with garlic clove extract were also reported to occur as a result of exposure of bacteria to other types of antimicrobial compounds. Lv et al. [21] previously documented cells with usual structures for untreated cells but those with increased permeability, disrupted membrane integrity, incomplete and deformed shapes as well as rupture, lysis and loss of cell walls for selected bacterial food pathogens treated with essential oils. An increase in size of bacteria after treatment with garlic was reported for Pseudomonas aeruginosa cells [2]. Cells elongate in order to increase their surface-to-volume ratio in response to changes in the environment [16].

Smooth intact cells with uniform cytoplasmic appearance for untreated bacteria and those with uneven cytoplasmic consistency and changed external structure for garlic clove treated cells as showed by TEM, were previously reported [21]. Exposure of lactic acid bacteria to bile acids induced similar internal morphological changes [27]. Treatment of Salmonella hadar cells with aqueous garlic extract resulted in loss of membrane integrity [6]. Deformation of cells, condensation of cellular material and presence of significant amounts of cytoplasmic material and membrane fragments have been reported for Campylobacter jejuni cells treated with garlic and garlic-derived organosulfur compounds [20]. Recently, Hatoum et al. [11] also reported TEM micrographs showing cell membrane perforation, cell lysis and leakage of cellular material in Listeria monocytogenes due to antimicrobial effects of compounds released by yeast cells. Cell wall lysis as well as reduction in cytoplasmic volume due to its aggregation has also been observed in bifidobacteria exposed to nisin [14]. Loss of cell contents evident from the SEM and TEM micrographs indicates irreversible damage to the cytoplasmic membranes. It is possibly as a result of accumulation of antimicrobial agent in the cell membrane, which is associated with an increase in permeability of the cell. The cells ultimately die due to leakage of cytoplasmic contents and impairment of enzyme systems [21]. 
Bacterial protein profiles are a reflection of its genome and therefore whole protein content plays a crucial role in comparative studies of bacteria [1]. Allicin kills bacteria through partial inhibition of DNA and protein synthesis and total inhibition of RNA synthesis [4]. Absence of visible differences in the whole cell proteins of treated and untreated bacteria may suggest that synthesis of the proteins is not affected, but that protective enzymes are inhibited in the presence of garlic [21]. It may also suggest a short exposure time of bifidobacteria to garlic as it has been indicated that an increase of incubation time of bacteria in the presence of antimicrobial compound led to presence of additional protein bands on SDS-PAGE gels [10, 25]. However, in the current study we did not increase the incubation time as our intention was to keep exposure period close to the retention time of food in the gastrointestinal tract. Reduction in the intensity of protein bands has been associated with inhibition of synthesis and expression of the protein in question by the toxic action of garlic or other plant extracts [25]. It was envisaged that should garlic have proteolytic activity on proteins, this would be indicated by disappearance of some protein bands and (or) appearance of additional bands on the gel. Disappearance of bands has been attributed to degradation of proteins by antimicrobial agents [3, 8]. Appearance of new bands could be due to production of proteins such as chaperones and signal transduction cascades that help bacteria to survive stressful condition [10], or in case of bands with low molecular weight, accumulation of smaller peptides from degraded high molecular weight proteins [3].

\section{Conclusion}

The current study is the first to reveal the mechanism of action of garlic clove extract on probiotic Bifidobacterium species. The results indicate that garlic clove extract damages or kills these beneficial bacteria in a manner similar to that exhibited in pathogens. These results therefore further highlight that caution should be taken especially when using raw garlic and probiotic bifidobacteria simultaneously as viability of these bacteria could be reduced by allicin released upon crushing of garlic cloves, thereby limiting the health benefits that the consumer anticipate to gain from probiotics.

\section{Acknowledgements}

The authors are grateful to the National Research Foundation (NRF) and the University of Pretoria for funding, the Unit for Microscopy and Microanalysis of the University of Pretoria, particularly Mr Alan Hall and Mr Chris van der Merwe for technical assistance, and Dr Michael Crampton of the Molecular Biology Division, BioSciences, CSIR, Pretoria, for assistance with SDS-PAGE analysis. 
Conflict of interest All authors have no conflict of interest to declare.

\section{References}

1. Aksakal, A (2010) Analysis of whole cell protein profiles of Salmonella serovars isolated from chicken, turkey and sheep faeces by SDS-PAGE. Vet Med-Czech 55:259-263

2. Alli JA, Boboye BE, Okonko IO, Kolade AF, Nwanze JC (2011) In-vitro assessments of the effects of garlic (Allium sativum) extract on clinical isolates of Pseudomonas aeruginosa and Staphylococcus aureus. Adv Appl Sci Res 2:25-36

3. Anas K, Jayasree PR, Vijayakumar T, Kumar PRM (2008) In vitro antibacterial activity of Psidium guajava Linn. leaf extract on clinical isolates of multidrug resistant Staphylococcus aureus. Indian J Exp Biol 46:41-46

4. Ankri S, Mirelman D (1999) Antimicrobial properties of allicin from garlic. Microbes and Infect $2: 125-129$

5. Bakri, I.M. and Douglas, C.W.I. (2005) Inhibitory effect of garlic extract on oral bacteria. Arch Oral Biol 50:645-651

6. Belguith H, Kthiri F, Ben Ammar A, Jaafoura H, Ben Hamida J, Landoulsi A (2009) Morphological and biochemical changes of Salmonella hadar exposed to aqueous garlic extract. Int J Morphol 27:705-713

7. Booyens J, Thantsha MS (2013) Antibacterial effect of hydrosoluble extracts of garlic (Allium sativum) against Bifidobacterium spp. and Lactobacillus acidophilus. Afr J Microbiol Res 7:669-677

8. Cloete TE, Thantsha MS, Maluleke MR, Kirkpatrick R (2009) The antimicrobial mechanism of electrochemically activated water against Pseudomonas aeruginosa and Escherichia coli as determined by SDS-PAGE analysis. J Appl Microbiol 107:379-384

9. Goncagul G, Ayaz E (2010) Antimicrobial effect of garlic (Allium sativum) and traditional medicine. J Anim Vet Adv 9:1-4

10. Hanina MN, Hairul Shahril M, Mohd Fazrullah Innsan MF, Ismatul Nurul Asyikan I, Abdul Jalil AK, Salina MR, Ahmad IB (2011) Protein production by Bacillus subtilis Atcc 21332 in the presence of Cymbopogon essential oils. World Academy of Sci Eng Technol 59:273-277 
11. Hatoum R, Labrie S, Fliss I (2013) Identification and partial characterization of antilisterial compounds produced by dairy yeasts. Probiotics Antimicro Prot 5:8-17

12. Jun-Sang H, Seung-Gyu L, Min-Kyung K, Mi-Hwa O, Seok-Geun J, Dong-Hun K, Se Hyung L, Jong Pyo C, Ji Yoon L, Dae-Kyung K (2010) Inhibitory activity of garlic fermented by Pediococcus pentosaceus KACC 91419 against antibiotic- resistant pathogens. Asian-Australas J Anim Sci $23: 1236-1243$

13. Kaur IP, Chopra K, Saini A (2002) Probiotics: Potential Pharmaceutical Applications. Eur J Pharmaceutical Sci 15:1-9

14. Kheadr E, Bernoussi N, Lacroix C, Fliss I (2004) Comparison of the sensitivity of commercial strains and infant isolates of bifidobacteria to antibiotics and bacteriocins. Int Dairy J 14:1041-1053

15. Kim JE, Choi NH, Kang SC (2007) Anti-listerial properties of garlic shoot juice at growth and morphology of Listeria monocytogenes. Food Control 18:1198-1203

16. Koch AL (1996) What size should a bacterium be? A question of scale?.Annu Rev Microbiol 50:317348

17. Lai-King NG, Sherburne R, Taylor DE, Stiles ME (1985) Morphological forms and viability of Campylobacter species studied by electron microscopy. J Bacteriol 164:338-348

18. Lemar KM, Passa O, Aon MA, Cortassa S, Müller CT, Plummer S, O’Rourke B, Lloyd D (2005) Allyl alcohol and garlic (Allium sativum) extract produce oxidative stress in Candida albicans. Microbiology $151: 3257-3265$

19. Lu X, Rasco BA, Kang DH, Jabal JMF, Aston DE, Konkel ME (2011a) Infrared and Raman spectroscopic studies of the antimicrobial effects of garlic concentrates and diallyl constituents on foodborne pathogens. Anal Chem 83:4137-4146

20. Lu X, Rasco BA, Kang DH, Jabal JMF, Aston DE, Lin M, Konkel, ME (2011b) Investigating antibacterial effects of garlic (Allium sativum) concentrate and garlic derived organosulfur compounds on Campylobacter jejuni by using Fourier transform infrared spectroscopy, Raman microscopy and electron microscopy. Appl Environ Microbiol 77:5257-5269

21. Lv F, Liang H, Yuan Q, Li C (2011) In vitro antimicrobial effects and mechanism of action of selected plant essential oil combinations against four food-related microorganisms. Food Res Int 44:3057-3064

22. Novik GI, Astapovich NI, Samartsev AA (2001) Investigation of the physiological and biochemical characteristics of bifidobacteria at the late stages of their development. Microbiology 70:429-435 
23. O’ Gara EA, Hill DJ, Maslin DJ (2000) Activities of garlic oil, garlic powder, and their diallyl constituents against Helicobacter pylori. Appl Environ Microbiol 66:2269-2273

24. Poupard JA, Husain I, Norris RF (1973) Biology of the Bifidobacteria. Bacteriol Rev 37:136-165

25. Saeed RMA, Zayed AA, El Namaky AH, Ismail HM, Mady HY (2010) Biochemical studies on Culex pipiens (L.) (Diptera: Culicidae) exposed to Allium sativum, Citrus limon and Bacillus thuringiensis israelensis with reference to assessment of the biosafety on albino mice. Global Veterinaria 4:22-33

26. Ruddock P S, Mingman L, Foster BC, Lawson L, Arnason JT, Dillon JAR (2005) Garlic Natural Health Products Exhibit Variable Constituent Levels and Antimicrobial Activity against Neisseria gonorrhoeae, Staphyloccocus aureus and Enterococcus faecalis. Phytother Res 19:327-334

27. Taranto MP, Perez-Martinez G, de Valdez GF (2006) Effect of bile acid on the cell membrane functionality of lactic acid bacteria for oral administration. Res Microbiol 157:720-725 